\title{
Cikkismertetés: Globális helyzetjelentés az alkoholról és egészségről 2018
}

\author{
Article review: Global status report on alcohol and health 2018
}

Ismertető: $\quad$ Virág Márk $\bowtie$
$\quad$ Pécsi Tudományegyetem Orvosi Népegészségtani Intézet

Ismertetett cikk: Global status report on alcohol and health 2018. Geneva: World Health Organization; 2018. Licence: CC BY-NC-SA 3.0 IGO https://www.who.int/substance abuse/publications/ global_alcohol report/en/

Beküldve: 2019.02.04.

doi: $\quad$ 10.24365/ef.v60i1.421

Kulcsszavak: alkohol; alkoholfogyasztás; alkoholfogyasztás hatásai; alkoholfogyasztás elleni intézkedések

Keywords: alcohol; alkohol consumption; effects of alcohol consumption; alcohol interventions

\section{BEVEZETÉS}

Minden jól és kevésbé ismert káros hatása ellenére, az alkoholfogyasztás számos kultúra, vallás és szociális szokás részét képezi, hazánkban éppúgy, mint a világ sok más országában. Az Egészségügyi Világszervezet (WHO) 2018-ban kiadott egy globális helyzetjelentést az alkoholfogyasztásról és annak egészségre gyakorolt hatásáról. A teljesség igénye nélkül az alábbiakban ebből a beszámolóból emelnék ki néhány gondolatot.

1. Fejezet: A káros alkoholfogyasztás csökkentése: kulcs a fenntartható fejlődéshez

A káros alkoholfogyasztás világszerte egyike a vezető kockázati tényezőknek az emberek egészségére nézve. Negatív hatással van fertőző (pl.: HIV, vírusos hepatitisz, tuberkulózis) és nem fertőző betegségekre (pl.: bizonyos daganatok, kardiovaszkuláris betegségek, mentális betegségek), sérülésekre és mérgezéses állapotokra. Fontosnak érzem megemlíteni, hogy mindezen káros hatások mellett az alkohol gyakran egyéb pszichoaktív szerekkel együtt kerül fogyasztásra, és a dohányfüggőséggel is erős kapcsolat mutatható ki.

Megemlítendő továbbá, hogy a felmérések szerint adott mennyiségű rendszeres alkoholfogyasztás nagyobb károkat okoz a szegényebb néprétegbe tartozó embereknek és családjuknak, mint a tehetősebbeknek.

A Fenntartható Fejlődési Keretrendszer 2030 (Agenda 2030) részeként kitǔzött célok majdnem mindegyike közvetlen vagy közvetett kapcsolatban áll a káros alkoholfogyasztással, ami szintén jelzi a helyzet jelentőséget.

\section{Fejezet: Globális stratégiák, akciótervek és követő rendszerek}

A globális és országonkénti monitorozás az alapja a hatékony intervenciónak. A célnak megfelelő monitorozásnak három kulcsindikátora az alkohol fogyasztás mértéke, az egészségi állapotra és a szociális életre gyakorolt hatás, valamint az intézkedések hatásának a nyomon követése. Fontos, hogy ügyeljünk a különböző országokban gyűjtött adatok összehasonlíthatóságára. A próbálkozások ellenére 
a nemzeti szintű felmérések számára továbbra is kihívást jelent a kereskedelmi forgalomban nem megjelenő alkohol, mint pl. a házilag készített szeszes italok.

A legköltséghatékonyabb preventív intézkedések közé tartozik az alkoholos árucikkek árának növelése, az alkohol reklámok kitiltása a különböző médiákból, és a fizikai elérhetőség korlátozása.

\section{Fejezet: Alkoholfogyasztás}

Körülbelül 2,3 milliárd ember fogyaszt rendszeresen alkoholt világszerte. 2010-ben a 15 éves vagy annál idősebb populációt figyelembe véve az egy főre jutó évente elfogyasztott tiszta szesz mennyisége 6,4 liter, ami 2005 óta 0,9 literrel emelkedett.

2000 óta szinte minden régióba nőtt az elfogyasztott alkohol mennyisége. Annak ellenére, hogy a globális trendekkel szemben az európai régióban 12,3-ról 9,8 liter tiszta szeszre csökkent az egy före jutó éves alkoholfogyasztás mértéke, még mindig ebben a régióban mérhető a legnagyobb érték. Európa szintén élen jár a 15-19 éves korosztály alkoholfogyasztását illetően, ebben a régióban 26,5\%-ra tehető a rendszeres alkoholfogyasztók száma.

Ha a szeszes italok típusa alapján csoportosítjuk az elfogyasztott alkoholt világszerte, akkor annak 44,8\%-a égetett szesz, 34,3\%-a sör, $11,7 \%$-a pedig bor.

A felmérések szerint mindegyik WHO régóban kevesebb az alkoholfogyasztó nő, mint férfi, és jellemzően alkalmanként is kevesebb alkoholt isznak férfitársaiknál. Az országok „gazdagsága” viszont nem mutat összefüggést lakóik alkoholfogyasztásának gyakoriságával.

Az "alkalmi nagy ivás" (alkalmanként minimum 60 gramm tiszta szesz, havonta legalább egyszer) prevalenciája világszerte csökkenő tendenciát mutat. 2000-ben még a teljes populáció 22,6\%-a tartozott ebbe a csoportba, míg 2016-ban már csak 18,2\%. Viszont a rendszeres alkoholfogyasztók között számuk továbbra is magas, főleg a kelet európai és subszaharai régióban. Arányuk a serdülők (15-19 év) között kisebb, csúcsértékét a 20-24 éves korosztályban éri el, ami a korcsoport szociális szokásait figyelembe véve talán nem is olyan meglepő.

\section{Fejezet: Egészségre gyakorolt hatás}

2016-ban a káros alkoholfogyasztás, kb. 3 millió ember halálát okozta (összes halálozások 5,3\%-a), és 132,6 millió elvesztett egészséges életévet (ELÉV, angolul: DALY) eredményezett. Az alkoholnak tulajdonítható halálozások 28,7\%-a baleset, 21,3\%-a emésztőrendszeri betegség, 19\%-a kardiovaszkuláris betegség, 12,9\%-a fertőző betegség, 12,6\%-a pedig rosszindulatú daganat következménye volt. Az említett ELÉV-ek 49\%-át nem fertőző betegség és mentális zavarok, 40\%-át pedig sérülések okozták.

\section{Fejezet: Irányvonal, intézkedések}

A káros hatású alkoholfogyasztás, a fizikai és szociális ártalmak fő megelőzhető kockázati tényezői közé tartozik. Éppen ezért számos törvény, jogszabály irányul korlátozására nemzeti, regionális és globális szinten egyaránt. A korlátozások mértéke országonként gyakran igen eltérő. Ennek szemléltetésére kiemelnék néhány példát az ismertetett beszámolóból.

Az országok többségében az ittas vezetés megelözésére véralkoholszint-határt vezettek be. Jellemzően 0,05\%-os ez az érték, de számos országban $0,08 \%$ vagy egyáltalán nincs ilyen jellegű korlátozás. A fiatalkorúak alkoholfogyasztásának megakadályozására több országban életkori megszorítások vannak érvényben. Ez legtöbb esetben 18 éves kort jelent, amit gyakoriságban a 21 majd 16 éves életkori megkötés követ.

Alkoholos italnak a 0,5\% feletti alkoholtartalmú italok számítanak. A monitorozó rendszerek az elfogyasztott alkohol mennyiségére és az egészségkárosító hatások feltérképezésére fókuszálnak, és kevésbé érintik a szociális következmények illetve a megelőző intézkedések felmérését.

A leghatékonyabb preventív beavatkozásnak az alkoholtartalmú italok árának emelése, a hozzájutás lehetőségének korlátozása és a marketingtevékenység szabályozása bizonyultak.

\section{Fejezet: A káros alkoholfogyasztás csökkenése}

A néhány pozitív globális trend ellenére, az alkoholhoz köthető morbiditás és mortalitás tekintetében, az egy főre jutó alkoholfogyasztást világviszonylat- 
ban továbbra sem sikerült mérsékelni.

A hatásos fellépést hátráltató tényezők között szerepelhet a gyenge politikai elköteleződés ennek a számos területet érintő probléma megoldásának koordinálására, amit az alkohol előállítása és árusítása mögött meghúzódó gazdasági érdekek, a népességbe erősen beivódott és alkoholhoz köthető kulturális szokások magyarázhatnak.

A káros alkoholfogyasztás visszaszorításának egyik fontos lehetősége, hogy építsünk a fiatalok alkoholfogyasztásának visszaszorítására és a populáció egészségtudatosságának növelésére.

\section{TANULSÁGOK A HAZAI SZAKEMBEREK SZÁMÁRA}

A WHO közleményéből is látszik, Magyarország egyértelműen a legtöbb alkoholt fogyasztó régió része, és a felsorolt egészségkárosodások is szép számban megfigyelhetők hazánkban. Mindezek felhívják a figyelmet arra, hogy a káros alkoholfogyasztás visszaszorítása egy fontos és sürgető népegészségügyi feladat, ahogy a világ többi részén, éppúgy Magyarországon is. 